\title{
Confidence in the Inter-organizational Cooperation of Social and Solidarity Economy Organizations
}

\author{
Wafa Affaghrou and Said Ahrouch
}

\begin{abstract}
Today, we are witnessing a growing enthusiasm for inter-organizational cooperation, as it has become the best path for managing organizations. Several authors and practitioners consider confidence as essential for the development and sustainability of this cooperation. According to Gambetta (1988) [1], confidence promotes cooperative behavior and promotes relationships between cooperants. For Social and Solidarity Economy organizations, interorganizational cooperation is an excellent way to demonstrate the proper use of the principles of confidence. This is a key factor in their success, which is reflected in the practice of their daily activities. Thus, drawing inspiration from the literature dealing with confidence, and according to the measurement criteria proposed by Mayer \& al., (1995) [2], we are conducting a quantitative study with three Economic Interest Groups (EIG) and four unions, composed of 59 cooperatives operating in d'Argane, located in Souss-Massa region. The goal is to show how confidence is built within these organizations. To what extent it influences inter-organizational cooperation.
\end{abstract}

Index Terms - Confidence, Inter-organizational cooperation, Social and Solidarity Economy.

\section{INTRODUCTION}

Nowadays, inter-organizational cooperation is a very popular strategy for companies looking for more competitive advantages and achievement of performance. Several studies in economics or management have analyzed the practice of cooperation that is established between organizations, with the development of several inter-organizational cooperation, in the form of alliance or partnership strategies [3]-[5]. Other authors have shown the interest of cooperation in relation to competition [6] and the survival of organizations [7]. The study the practice of inter-organizational cooperation makes it possible to highlight the existence of formal and informal approaches born from interactions between members of cooperating organizations. As a result, confidence is a key element in the functional exercise of this cooperation, which enables the partners to cooperate and face short-term hazards in order to favor long-term interests [8]-[12]. It thus leads to cooperative behaviors favoring success [13], [14], [10]. Many authors claim that confidence plays a major role in inter-organizational exchanges. It is the basis of performance [15], which promotes the success of interactions. Thus, the organizations of the Social and Solidarity Economy are also concerned with cooperation because they are faced with a very powerful environment which endangers not only their economic survival but also their identity [16]. Confidence for these organizations measures the degree of consolidation of

Published on December 30, 2020.

Wafa Affaghrou, PhD student, Research Team in Management of Social and Territorial Organizations (RTMSTO), Faculty of Legal and Economic Sciences of Agadir, Ibn Zohr University, Morocco.

(corresponding e-mail: wafa.affa@gmail.com) their principles in an economy that seeks to articulate economic objectives and social values. Today the development of cooperative groups and unions in Morocco shows that confidence is a main component in the construction of inter-organizational cooperation relations and allows these organizations to be led towards the desired development path. Our article aims to analyze confidence within these organizations through the case study of seven cooperations located in Souss-Massa region. The article is structured in three parts. The first part theoretically frames this paper based on the theory of confidence. The second part presents the research methodology adopted. To this end, the last part tackles the presentation and discussion of the results.

\section{THEORETICAL FRAMEWORK}

The literature review allowed us to highlight the concepts of cooperation, inter-organizational cooperation relations and the theoretical framework mobilized based on the theory of confidence.

A. Inter-organizational Cooperation

$>$ The concepts of cooperation and inter-organizational cooperation

The word "cooperation" is not universal. It is very common and is synonymous with several terms such as coordination, collaboration, and partnership. Its definition differs according to its context of use [17]. Larousse dictionary defines cooperation as "an economic method by which people with common interests constitute a company where everyone's rights to management are equal and where the profit is distributed only among the partners in proportion to their activity". Several definitions of cooperation are given in the literature. For economists, cooperation is a strategy for implementing partnership relationships to meet market demands. For sociologists, cooperation is an alternative to competitive behavior. Therefore, it is a collective action, which contributes to the same result [18]-[20]. The sharing of objectives, common interests, skills, and resources [21] motivates it. It helps strengthen competitiveness through the acquisition of new knowledge and the ability to work together [22]. Several aspects encourage inter-organizational cooperation, for some authors it is the continuous increase in the complexity of market relations and the development of several forms of grouping between organizations [23]. From this perspective, the inter-organizational cooperation relationship is a formal or informal agreement, lasting over

Said Ahrouch, Teacher-researcher, Research Team in Management of Social and Territorial Organizations (RTMSTO), Faculty of Legal and Economic Sciences of Agadir, Ibn Zohr University, Morocco.

(e-mail: s.ahrouch@uiz.ac.ma) 
time, between independent organizations, which pool assets, and resources for the purpose of efficiency or effectiveness [24]. In addition, inter-organizational cooperation is considered as a relational strategy alongside confrontation and avoidance [25], [26]. The relational approach “... seeks to build a theory in which policies of protective cooperation and strategies of confrontation can co-exist. In other words, two types of business behavior, relational and competitive, can be observed simultaneously in the economic world" [27]. In this perspective, confidence is a fundamental element in cooperative relations between companies encourageing partners to cooperate in order to resist short-term attractions and favor long-term interests [8]-[12]. The stake for the company lies primarily in identifying the criteria of this confidence, which allow the sharing of common constraints and the management of asymmetry of information, throughout the dynamic process of inter-organizational cooperation.

\section{$>$ Definitions of authors}

There is no consensus on the definition of interorganizational cooperation. Many authors have given meaning to inter-organizational cooperation. Thus, it is specified by contractual relationships based on the writings and / or relational based on confidence.

TABLE I: DEFINITIONS OF THE CONCEPT OF INTER-ORGANIZATIONAL COOPERATION

\begin{tabular}{|c|c|c|}
\hline Authors & Definitions & Contributions \\
\hline [28] & $\begin{array}{l}\text { Inter-organizational cooperation agreements encourage the parties } \\
\text { to accept obligations and in return provide guarantees as to their } \\
\text { future conduct. }\end{array}$ & $\begin{array}{l}\text { An approach, which challenges the notion of the } \\
\text { organization that brings together the cooperating, } \\
\text { parties and formalizes the relations that can be } \\
\text { formal and / or informal relations. }\end{array}$ \\
\hline [29] & $\begin{array}{l}\text { It is an agency relationship through a contract, in which a person (or } \\
\text { several persons) uses the services of another person to accomplish } \\
\text { any task on their behalf, which implies a delegation of a decision- } \\
\text { making nature to the 'agent. }\end{array}$ & $\begin{array}{l}\text { A contractual cooperation relationship challenges } \\
\text { the definition of the firm's borders. It is a very } \\
\text { important comparison tool in relationships. }\end{array}$ \\
\hline$[30],[31]$ & $\begin{array}{l}\text { It is a contractual approach for the completion of activities. It is } \\
\text { achieved through the signing of a contract. }\end{array}$ & $\begin{array}{l}\text { Writings and contractual agreements are the basis of } \\
\text { cooperation between organizations. }\end{array}$ \\
\hline$[32]$ & $\begin{array}{l}\text { It is a hybrid organizational form of governance of economic } \\
\text { activities. It is situated between the hierarchy and the market. }\end{array}$ & $\begin{array}{l}\text { An intermediate organization between the market } \\
\text { and the hierarchy. It is based on the formal aspect of } \\
\text { relations. }\end{array}$ \\
\hline$[33]$ & $\begin{array}{l}\text { It is a mode of organization that can be used by managers and } \\
\text { entrepreneurs to position their companies in a strong competitive } \\
\text { position. }\end{array}$ & $\begin{array}{l}\text { A proactive strategy to support competitive } \\
\text { advantage and face competitors while maintaining } \\
\text { their independence. }\end{array}$ \\
\hline [34] & $\begin{array}{l}\text { Inter-organizational cooperation is based on trust and interpersonal } \\
\text { relationships. }\end{array}$ & $\begin{array}{l}\text { The contract is not necessary when confidence } \\
\text { promotes cooperative behavior. }\end{array}$ \\
\hline$[35]$ & $\begin{array}{l}\text { Two companies or other organizations form social, economic, } \\
\text { technical, or service relationships, over time with the intention of } \\
\text { reducing total costs and / or increasing value creation through a } \\
\text { process. }\end{array}$ & $\begin{array}{l}\text { The search for efficiency (cost reduction) and } \\
\text { effectiveness (value creation) all remaining } \\
\text { autonomous in their management. }\end{array}$ \\
\hline$[36]$ & $\begin{array}{l}\text { Inter-organizational cooperation is not just about the transaction, but } \\
\text { more about the way relationships work. }\end{array}$ & $\begin{array}{l}\text { Cooperation is built through formal and informal } \\
\text { relationships. }\end{array}$ \\
\hline [37] & $\begin{array}{l}\text { It is a way to enhance the complementary resources, knowledge, } \\
\text { skills or capacities between cooperants. }\end{array}$ & $\begin{array}{l}\text { The sharing of resources is formalized by contractual } \\
\text { modalities rather than informal relationships. }\end{array}$ \\
\hline$[38]$ & $\begin{array}{l}\text { It is a calculated relationship strategy between independent firms } \\
\text { that share compatible goals, strive for mutual benefit, and recognize } \\
\text { a high level of interdependence. }\end{array}$ & $\begin{array}{l}\text { The interdependence of the actors must guarantee } \\
\text { the superiority of collective objectives over } \\
\text { individual objectives. }\end{array}$ \\
\hline [39] & $\begin{array}{l}\text { To cooperate is to seek if there are possible inter-organizational } \\
\text { cooperation links between partners. }\end{array}$ & $\begin{array}{l}\text { Cooperation is based on learning and the sharing of } \\
\text { skills between firms, which calls for formal or } \\
\text { informal relationships. }\end{array}$ \\
\hline$[40]$ & $\begin{array}{l}\text { It is the sharing of resources in order to complement each other in a } \\
\text { specific context. }\end{array}$ & $\begin{array}{l}\text { Inter-organizational cooperation is a solution to } \\
\text { achieve performance. }\end{array}$ \\
\hline [41] & $\begin{array}{l}\text { It is a hybrid form between the market and the organization, which } \\
\text { includes various entities located on the same value chain with } \\
\text { common interests and privileged modes of interaction and } \\
\text { coordination. }\end{array}$ & $\begin{array}{l}\text { Sharing of objectives between companies belonging } \\
\text { to the same value chain. }\end{array}$ \\
\hline [42] & $\begin{array}{l}\text { Inter-organizational cooperation is defined as a pooling of resources, } \\
\text { skills, knowledge, and information. }\end{array}$ & $\begin{array}{l}\text { Inter-organizational cooperation promotes the } \\
\text { sharing of knowledge and skills. }\end{array}$ \\
\hline
\end{tabular}

Source: according to the literature review.

In short, we can define inter-organizational cooperation as an entity that brings together several actors around a common objective, this cooperative relationship can take different natures depending on circumstances and temporal situations. The majority of definitions identified above treat inter-organizational cooperation from two perspectives that can be found explicitly or implicitly. These formal and informal relationships can exist in the relationships between actors and their environment. The formal perspective of cooperation highlights an identified and visible structure, such as networks, unions and groupings. Its role is to coordinate between several actors. The contracts, written conventions and partnership agreements are all formal relationships that constitute the visible part of interorganizational cooperation. Whereas the informal perspective alludes to relationships based on trust.

\section{B. The Theory of Confidence}

\section{$>$ The concept of confidence}

Changes in the political, social, and business environment have increased asymmetries between organizations. Confidence has become the foundation for consolidating 
relationships in this context. It is a polysemous concept, present in most relationships. In the literature, several conceptions are opposed in the definition of confidence and the establishment of its precise explanation. Etymologically, confidence comes from the Latin word: confidentia, which is defined as a "feeling of someone who relies on someone else or on something" [43]. Most definitions of confidence focus on the interpersonal level [44]. Nonetheless, several theories address confidence as applied to individuals, groups and organizations. The decisions made by these three actors are similar and make it possible to apprehend confidence through measurable actions. Researchers have studied confidence as a general concept in relation to the decisionmaking of individuals [45], groups [46], and organizations [47]. In addition, the shift from interpersonal confidence to intergroup confidence requires an inter-organizational view [48]. However, it is difficult to study confidence at one level by examining it at another level [49]. This is why confidence has long been a controversial and debatable topic in philosophy and the social sciences. Fukuyama [50], in his bestseller said "confidence: the social virtues and the creation of prosperity". In their study McEvily \& al. [51] suggested the following definition "trust is the willingness to accept vulnerability based on positive judgments, expectation on another's intentions or behaviors". Likewise, Zucker [52] describes confidence as "a set of logical expectations shared by all, involved in an economic exchange". Antit [53], for its part, remains on the same thought and affirms that trust is the acceptance of a vulnerable individual or the desire for a vulnerability in relation to the partner [53]. Confidence is defined by Rousseau \& al. [44] and Sitkin \& Roth [54] as a psychological state integrating the acceptance of vulnerability based on the expectation of positive intentions and behaviors; from the other party, it is the feeling experienced by each other during the interaction, in a way that is in accordance with their interests. According to the vast majority of authors [55], interpersonal trust is the subjective probability by which an individual expects another individual to perform a given action on which their well-being depends. This definition emphasizes that confidence is a belief. However, it is not complete, because there are several determinants of trust other than benevolence, namely: integrity and competence [56]. From this, we deduce that confidence is a very complex term in its definition, it is perceived in different ways depending on the situations where it is addressed.

\section{$>$ Definition of authors}

Subsequently, we present the opinion of some authors (Table 2).

Despite its founding role in any social and relational exchange, confidence remains a concept that is difficult to define. Moreover, it is not easy to apply it similary in all fields of research. Its operationalization is as complex as its definition thus, we adopt the universal approach of Mayer \& al. [2], according to which confidence is a three-dimensional concept composed of benevolence, integrity, and competence. It can take many facets, depending on the circumstances of the situation and the people using it.
TABLE II: DEFINITIONS OF CONFIDENCE

Definitions

The willingness of one party to be vulnerable to the actions of another party regardless of the ability to monitor or control it.

The risk or willingness to invest is essential to confidence; confidence is evident in situations where the potential damage to unfulfilled confidence is greater than the possible gain than if the confidence is fulfilled.

Confidence involves taking risks and some forms of confidence are inherent in all relationships.

Willingness to take risks (one of the few characteristics common to all confidence situations).

Cognitive refers to the belief about the reliability of the other.

Cognitive confidence refers to the important role of emotions in the process of confidence.

Behavioral confidence builds on the other's behavior and their disclosure of sensitive information.

Accept the risks associated with the type and depth of interdependence inherent in a given relationship.

It is a belief shared by members of a contact group about how these members are prepared to be vulnerable to each other.

Confidence involves a belief that a person does not have to act opportunistically or in a selfish manner, the belief of a congruence of values.

A psychological state compromising the intention to accept vulnerability based on positive expectations of the intentions or behaviors of another party.

A willingness to rely on the actions of others in a situation involving the risk of opportunism.

We believe in being ready to depend on another party. Source: [67].

Authors

\section{Forms of Confidence}

Trust is built over time and therefore cannot appear and disappear instantly [68]. Zucker (1986) [52] identifies three main forms of confidence:

-Confidence intuitu personae: it is characterized by a sharing of values approaching the logic of the Ouchi clan [69] where strong links exist between the members. This type of trust is seen as intrinsic to individuals. It can therefore neither be transmitted nor taught to others. In relationships where this type of confidence is established, the notion of a code of honor is very strong, with a rapid sidelining of the one who breaks it.

-Institutional trust: it is characterized by the application of formal rules and generally on codes of conduct imposed by the cooperants. These rules are considered "the guardians of confidence" [70]. This form of trust is not then pre-existing in relationships, but it was born out of rules guaranteeing an institutional framework that increasingly consolidates relationships. It participates in the construction of a collective identity of the cooperation group.

-Relational confidence: this form of relationship is established as the cooperative relationship progresses. It is part of a mutual learning process that is established throughout the relationship. This trust is then fostered by behaviors showing loyalty, goodwill, and benevolence [71] Moreover, it is not easy to apply the concept of confidence in a similar way to all areas of research. Its operationalization is as complex as its definition thus, we adopt the universal approach of Mayer \& al. [2], according to which trust is a three-dimensional concept composed of benevolence, integrity, and competence. 


\section{Indicators to Measure Confidence}

Several theorists have addressed the question of measuring confidence and have been able to deduce that it is a complex mental state to define and measure. The dimensions of confidence do not seem to lead to any consensus and the dimensions retained vary widely. Depending on the perception retained, confidence can be measured according to integrity, benevolence, good will, uncertainty, confidence, or credibility [72]. In order to clarify the choice of criteria retained, we study the dimensions of confidence according to the types of perceived or objective measures. From this, measuring confidence is as complex as its definition. For Pavlou [73], confidence describes two perceived characteristics of the partner organization: credibility and benevolence. For Bergadaà \& al. [74], it is linked to the competence of the other, his benevolence as well as his credibility. For Mayer \& al. [2], it is a construct compsed of three dimensions: benevolence, integrity, and competence.

TABLE III: THE MAIN INDICATORS FOR MEASURING CONFIDENCE

\begin{tabular}{ccc}
\hline \hline Author & Context & Components \\
\hline \multirow{2}{*}[9]{} & Buyer / Seller Relations: & Credibility \\
& Long-term confidence & Benevolence \\
& Inter-organizational relations: & Benevolence \\
[2] & Confidence and performance & Skill \\
& Inter-organizational relations: & Reliability \\
{$[2]$} & Confidence and performance & Integrity \\
& Building buyer / seller confidence & Credibility \\
{$[12]$} & & Benevolence \\
& & Honesty \\
& & Integrity \\
{$[75]$} & Confidence and partnership & Reliability \\
& & Responsibility \\
& & Skill \\
{$[74]$} & Confidence and cooperation & Benevolence \\
& & Credibility \\
& & Credibility \\
& & Benevolence \\
\hline \hline
\end{tabular}

Source: Adapted, Chaker Boughanbouz [67].

Despite the fact that the majority of authors treat trust according to several dimensions. We find that the variables that most define trust are:

- Kindness.

- Integrity.

- Competence.

In what follows, we tackle the criteria used by Mayer \& al. [2]:

\section{$\checkmark$ Kindness}

Several authors have adopted benevolence, as an important emotional dimension of confidence. It is the belief in a positive behavior of the other towards oneself. It schematizes the content of collective attention and interest in acting for others [76]. Benevolence can be approached in two distinct ways, altruistic benevolence, and mutual benevolence. Altruistic benevolence is maintained on the attitude directed towards the desire to achieve good for others, in the absence of a counterpart [2]. With regard to mutual benevolence, it manifests itself in the attitude of devoting oneself to the well-being of the other party in order to enjoy common advantages [12].

\section{$\checkmark$ Integrity}

Integrity is an essential component of an organization's culture, because the most important thing for an organization is to combine its values and financial goals, while maintaining sustainable growth. A culture of integrity must reflect the attitudes and activities of managers and decisionmakers. They must develop confidence based on shared values [77]. Overall, integrity is the extent to which the actions of the confidenceee reflect the values that are acceptable to the confidenceor [78]. In other words, integrity is established by following a set of rules and ethical standards of conduct.

\section{$\checkmark$ Competence}

Competence is a key factor in confidence [79]. Indeed, when confidence is based on competence, it can be built quite quickly [80]. In the inter-organizational context, confidence is measured according to two criteria: competence-based confidence and goodwill confidence. The first refers to competence [81], expertise, ability [58] and skill [82]. It is also the perception in the capacity of the other party to undertake to respect the obligations and achieve the desired objectives [83]. The second uses long-term capacity rather than competence, in order to better describe futureoriented cooperation [84]. We then present the main variables for measuring confidence.

\begin{tabular}{clc}
\multicolumn{3}{c}{ TABLE IV: INDICATORS FOR MEASURING CONFIDENCE } \\
\hline \hline \multirow{4}{*}{ Benevolence } & \multicolumn{1}{c}{ Measurement indicators } & Authors \\
\hline & - Partner's well-being & {$[12]$} \\
& - Participation in the reputation of the firm & {$[85]$} \\
& - Taking into account the interests of the & {$[86]$} \\
& other & \\
Integrity & - Follow each other's culture & {$[87]$} \\
& - Shared values & {$[88]$} \\
& - Rules and ethical standards of conduct & \\
& - Compliance with formal work & {$[89]$} \\
Skill & requirements & {$[58]$} \\
& - Degree of expertise & {$[82]$} \\
& - Skill required & {$[83]$} \\
\hline \hline
\end{tabular}

\section{Confidence as a Measure of Inter-organizational Cooperation}

The literature defines inter-organizational cooperation as a sharing of objectives, common interests, skills, and resources between cooperants. This definition includes the idea that cooperation is a shared collective action based on behavior of a relational and / or functional nature, which takes the contractual and / or informal framework [21]. However, Peillon [90] specifies that confidence is essential for inter-organizational cooperation from a dynamic perspective, while in the static framework contracts are more effective. Therefore, confidence is an important factor for the development of cooperation between organizations, likewise, cooperation is a favorable place for the growth of confidence. This is anticipation in relation to partners' expectations regarding the development of relations [91] [52], throughbenevolence in their actions for the interests of the other party [92]. Ultimately, cooperation and confidence must be seen in a complementary role for the regulation of inter-organizational relations [93]. In what follows, we examine the relationship between confidence and interorganizational cooperation in the cooperation of organizations of the Social and Solidarity Economy. 


\section{E. Confidence in Social and Solidarity Economy organizations}

The Social and Solidarity Economy is made up of cooperatives, mutual societies, and associations whose objectives are the production and supply of goods or services useful to their members or to the community. These organizations are called upon to cooperate and form solid relationships with each other in order to face a very hostile environment [94]. Cooperation within this economy takes several forms, groupings, unions, networks, or federations. Even if the current economic situation is marked by instability, these forms of cooperation must instil confidence in their relations [95]. This objective justifies the fight against the misconfidence, which marks the movements of the capitalist world. Confidence in these organizations makes it possible to consolidate the cooperative relations necessary for their development. Two perceptions of confidence are distinguished: interpersonal confidence and inter-organizational confidence. Interpersonal perception is the legitimate definition of confidence [96], [97], while interorganizational confidence is that granted by cooperants to the organization that associates them [98], it is based on formal systems of procedures and standards [52]. For, Khalifa and Kammoun [99], the two paths of confidence influence each other. Thus, interpersonal confidence can be at the origin of organizational confidence and vice versa [12]. In the organizations of the Social and Solidarity Economy, cultural and institutional proximity allow actors to coordinate with each other, confidence represents, in the context of their cooperation, an important dimension to approve the will of the cooperants against the risks of decision-making collective [100]. In Morocco, the cooperation of organizations of the Social and Solidarity Economy constitutes a favorable space for the strengthening and development of personal and organizational links. The EIG and the unions, formed by a set of cooperatives, have the role of strengthening the production capacity and increasing the distribution channels of their members. They are "aggregation bodies of small farmers able to carry out economically viable and socially inclusive development projects" [101]. They participate in implementing all their own means in order to facilitate the economic activity of their members and strengthen their social values. Thus, through this article, we measure the construct of confidence and its role in the inter-organizational cooperation of these organizations.

\section{A. Study Population}

\section{METHODOLOGY}

In Morocco, women's cooperatives of Argane are responsible for the production of various Argane products. Today, the majority of these cooperatives are integrated into groups, unions, networks or federations. The objective of these cooperations is the economic and social development of women and their cooperatives on the one hand and the enhancement and protection of the argan grove on the other. Our field of study will focus on EIGs and unions of cooperatives operating in Argane. These forms of interorganizational cooperation aim to create a favorable environment for often-marginalized women. Thus, less main missions of these organizations are :

- Promotion and marketing of the products of member cooperatives.

- Access to the market by freeing itself from intermediaries.

- The promotion of ancestral know-how.

- Improving the socio-economic situation of women.

- Empowerment of women benefiting from training and paid work.

- Access to group purchasing.

According to our documentary research and the interviews conducted, cooperatives are led to increase their performance and guarantee their sustainability, by integrating groups and unions that can promote them towards the hoped-for objectives. Therefore, our field of study is made up of all the EIGs and unions of cooperatives operating in Argane in the region of Souss Massa.

TABLE V: EIGS AND UNIONS OF COOPERATIVES OPERATING IN ARGAN IN SOUSS MASSA

\begin{tabular}{ccccc} 
Names & $\begin{array}{c}\text { EIG or } \\
\text { Union }\end{array}$ & $\begin{array}{c}\text { Number of } \\
\text { members }\end{array}$ & $\begin{array}{c}\text { Number of } \\
\text { members }\end{array}$ & Locality \\
\hline Tissaliwine & Union & 17 & 1800 & Agadir \\
Targhanine & EIG & 6 & 240 & Agadir \\
Tifouat NG & Union & 8 & 405 & Agadir \\
Rodana & Union & 7 & 418 & Taroudant \\
Tizargane & EIG & 5 & 175 & Tiznit \\
Ethical W & EIG & 10 & 530 & Agadir \\
Targant TZT & Union & 6 & 120 & Agadir \\
Total & & 59 & 3688 & \\
\hline
\end{tabular}

Source: IFA [102].

To study confidence within these organizations, we recommend an exploratory methodological approach, which allows us to test our words through a quantitative study.

\section{B. Data Processing}

In order to study confidence following interorganizational cooperation. We involved all the groups and unions ( 3 EIGs and 4 unions) of cooperatives operating in the Argane in the Souss Massa region (59 cooperatives). These organizations are recognized for their dynamism and their very marked participation in the economic and social development of the region. In addition, the availability of information through their management teams has enabled us to pass judgment on the building of confidence within these organizations on the one hand, and its influence on cooperation relations on the other. Therefore, our methodological approach is presented as follows:

\section{Collection of data}

The research required several pre-liminary contacts, through individual and semi-structured interviews carried out with a few managers of EIGs, unions and cooperatives in the region, as well as some profession-als from the Social Affairs Division, the Interprofessional Federation of the ARGANE Sector and the Office for De-velopment and Cooperation. To achieve our research ob-jective, we have adopted the quantitative method. This choice depends on our research approach, and our desire to obtain better quality results. The measuring instrument that we have chosen is a questionnaire developed from our theoretical study and the interviews carried out. The role of this questionnaire is to measure the perception of confi-dence within organizations 
of the Social and Solidarity Economy. Therefore, we carried out an exhaustive survey of EIGs and unions of coopera-tives operating in Argane in the Souss Massa region. We surveyed 59 cooperatives.

\section{Data analysis methods}

The presentation of the quanti-tative study took place in two stages: first, according to the Exploratory Factor Analysis (EFA) method, which is inter-ested in the analysis of the raw data collected and makes it possible to validate the measurement scales, according to the criterion proposed by Evrard et al. [103] greater than or equal to 0.5. Subsequently, recourse to Confirmato-ry Factor Analysis (CFA) allows us to estimate the con-struct validity of our variable (confidence) with SPSS 24 software. The CFA is a tool used to verify the stability of the factor structure. Moreover, it facilitates the convergent and discriminant validity of the scales [104]. Thus, the reliability of the factors detected is meas-ured by Cronbach's alpha, KMO criterion and Barlett test, less sensitive to the number of items analyzed [105], [106]. Then, the coherence of the factors detected is evaluated by Spearman's Rho correlation coefficient. The second phase was according to the descriptive statistical tool, which is interested in measuring the construct of confidence and deducing its relationship with inter-organizational cooperation, using the Khi2 criterion. The Chi-square statistical test indicates that the measurement model is adequate with regard to the theoretically accepted standards and it leads to accept the adjustment of the theoretical model to the empirical data as a whole.

\section{Measurement indicators}

Confidence is a three-dimensional concept measured according to the three di-mensions (benevolence, integrity, and competence) pro-posed by Mayer et al. [2]. It influences cooperation and vice versa [21].

Thus, the operationalization of our research theme will be based on the following variables:

TABLE VI: THE EXPLANATORY VARIABLES OF THE CONSTRUCT OF

\begin{tabular}{|c|c|c|}
\hline \multicolumn{3}{|c|}{ CONFIDENCE } \\
\hline Dimension & Coded & Items \\
\hline \multirow{4}{*}{ Benevolence } & Benev.1 & $\begin{array}{l}\text { The co-workers are concerned about the } \\
\text { well-being of the partner. }\end{array}$ \\
\hline & Benev.2 & $\begin{array}{l}\text { The cooperants are concerned about the } \\
\text { reputation of the EIG or the union. }\end{array}$ \\
\hline & Benev.3 & $\begin{array}{l}\text { The cooperants take into account the } \\
\text { interest of the other partner. }\end{array}$ \\
\hline & Benev.4 & $\begin{array}{l}\text { Cooperants have good intentions } \\
\text { towards others. }\end{array}$ \\
\hline \multirow{3}{*}{ Integrity } & Integrated 1 & Cooperants are loyal in our relationship \\
\hline & Integrated 2 & $\begin{array}{l}\text { We appreciate the values of our } \\
\text { cooperants }\end{array}$ \\
\hline & Integrated 3 & $\begin{array}{l}\text { Cooperants are guided by ethical } \\
\text { principles }\end{array}$ \\
\hline \multirow{3}{*}{ Skill } & Skill.1 & Cooperants respect their obligations \\
\hline & Skill.2 & $\begin{array}{l}\text { We confidence the knowledge of our } \\
\text { partners. }\end{array}$ \\
\hline & Skill.3 & $\begin{array}{l}\text { Cooperants are well qualified in the } \\
\text { work they do. }\end{array}$ \\
\hline
\end{tabular}

TABLE VII: THE CROSSED VARIABLES

\begin{tabular}{ccc}
\hline \hline Dimension & Coded & Items \\
\hline Cooperation & degreeCoop & $\begin{array}{c}\text { The degree of satisfaction of } \\
\text { cooperation by the } \\
\text { cooperants }\end{array}$ \\
Confidence & degreeConf & $\begin{array}{c}\text { The degree of confidence } \\
\text { between cooperants }\end{array}$ \\
\hline \hline
\end{tabular}

\section{RESULTS AND DISCUSSION}

In the light of the survey carried out among the EIGs / Unions and their members in the Souss Massa region, we measured the construct of confidence and its relationship with inter-organizational cooperation. The results obtained are processed according to the technique of bivariate and multivariate descriptive statistics.

\section{A. Survey Results}

To present the results, we used different statistical methods suggested by the literature in order to cross several acceptance criteria.

\section{$>$ Building confidence within SSE organizations}

Through the technique of factor analysis, we measured the construct of confidence in EIG / Unions and their members. Thus, the results of the validation test show that the majority of variables are reliable for our confirmatory analysis (Table VIII).

The study of the correlation matrix indicates that the confidence items stopped all have a value very much greater than 0.5 . Then, the matrix of final components, extracts two main components, which have scores clearly close to one. The items of integrity and competence are all retained, for benevolence three items are retained; only item 2 is extracted far from the validity threshold than the others analysis (Table VIII).

TABLE VIII: THE MATRIX OF COMPONENTS OF CONFIDENCE

\begin{tabular}{cccc}
\hline \hline Strong confidence & Score & $\begin{array}{c}\text { Low } \\
\text { confidence }\end{array}$ & Score \\
\hline Integrity 1 &, 919 & Benev 1 &, 835 \\
Integrity 2 &, 888 & Benev 3 &, 883 \\
Integrity 3 &, 876 & Benev 4 &, 839 \\
Skill 1 &, 858 & & \\
Skill 2 &, 825 & & \\
Skill 3 &, 868 & & \\
\hline \hline
\end{tabular}

TABLE IX: THE TOTAL VARIANCE EXPLAINED

\begin{tabular}{cccc}
\hline \multirow{2}{*}{ Components } & \multicolumn{3}{c}{ Sums extracted from the load square } \\
\cline { 2 - 4 } & Total & $\begin{array}{c}\% \text { of } \\
\text { variance }\end{array}$ & Cumulative \% \\
\hline 1 & 5.228 & 52.280 & 52.280 \\
2 & 3.054 & 30,540 & 82,820 \\
\hline \hline
\end{tabular}

The variables of integrity and competence are grouped together in component 1 with a significant variance of 52 , $28 \%$, which leads us to consider these variables as a source of strong confidence. Whereas the benevolence variable is grouped together in component 2 with a variance of $30,54 \%$, which is why we named it low confidence. Thus, the cumulative variance represents a satisfactory percentage $(82$, $82 \%$ ) for studying the construct of confidence (Table IX and $\mathrm{X})$.

Reliability corresponds to the degree to which the research instruments used measure, in a constant way, the studied construct. Cronbach's alpha is a commonly used reliability indicator for metric-type measurements. We obtain satisfactory results for this indicator $(\alpha=0.804)$. In addition, the KMO test measures the adequacy of the sampling; it gives a global overview of the quality of the inter-item correlations. The KMO index shows a good correlation if it approaches 1 . In our case, it is 0.838 , which indicates a good capacity of the data to be factored. Bartlett's test has a significant chi-square, which which allows us to conclude 
that the correlations between the variables are therefore all zero (Table XI).

The statistical tests presented indicate that the measurement model is not adequate with respect to previously accepted norms, hence, the adjustment of the theoretical model to the empirical data is not justified in its entirety. Noting that on the matrix of components, benevolence is separated from the other two variables, it approaches 1 of axis 2, while the variables of integrity and competence approach 1 of axis 1 Thus, confidence is explained by two distinct variables: integrity and competence on the one hand and benevolence on the other. We then measure the correlation between the two components, strong confidence for component 1 and low confidence for component 2.

We notice in figure 1 , that the items of benevolence make up a cloud of instinct points. While the two criteria of integrity and competence are concentrated in the same place. This leads us to confirm the results of the component matrix; benevolence is far from being a component of trust in our case. Our exploratory survey allowed us to verify that the notion of confidence is a variable that is based mainly on the seriousness and experience of the cooperants, while benevolence is an indicator rarely raised by our survey.

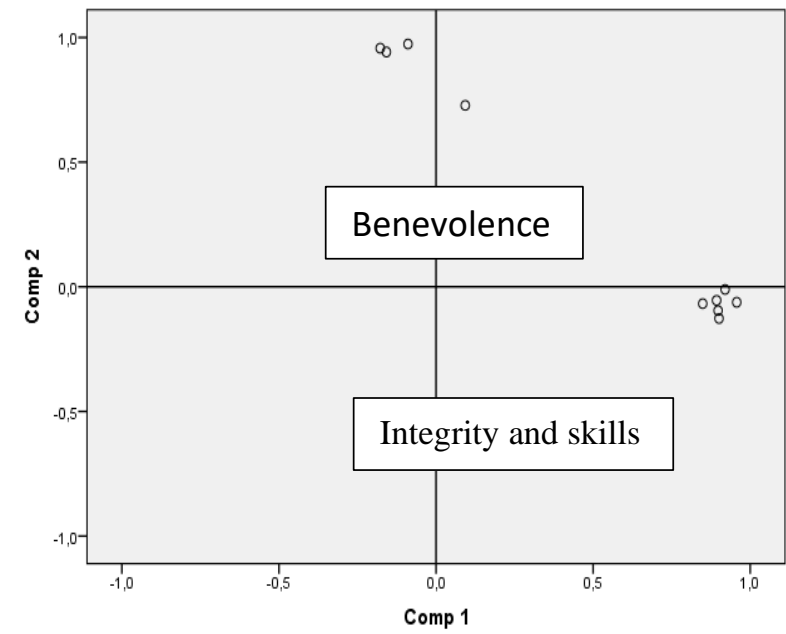

Fig. 1. the variable arrangement matrix.

TABLE X: MEASURING THE RELIABILITY OF THE VARIABLES

\begin{tabular}{cc}
\hline \hline $\begin{array}{c}\text { Percentage of variation explained } \\
\text { Cronbach Alpha }\end{array}$ & $82.82 \%$ \\
Cronbach's alpha based on standardized &, 776 \\
elements &, 804 \\
KMO &, 838 \\
Bartlett &, 000 \\
\hline \hline
\end{tabular}

TABLE XI: MEASURING THE CORRELATION BETWEEN STRONG CONFIDENCE AND LOW CONFIDENCE

\begin{tabular}{lccc}
\hline \hline \multirow{2}{*}{ Spearman's Rho } & Strong confidence & 1,000 &, 233 \\
& Low confidence &, 233 & 1,000 \\
\hline \hline
\end{tabular}

The analysis of the confirmatory test approves the validity of the data to be factored, but it reveals two distinct groups for the explanation of the confidence. The correlation test confirms the mismatch between the strong confidence variables and the weak confidence variables. A weak correlation of 0.233 , which supports the results given by the descriptive statistics (Fig. 2-4). That is to say that building confidence within EIGs and unions does not confirm the basic hypothesis.
The assessment of confidence and its relation to interorganizational cooperation

The literature review enabled us to define trust according to several approaches. The most widely accepted definition can be understood as "Trust is a psychological state comprising the intention to accept vulnerability based upon positive expectations of the intentions or behavior of another" [44]. In our case, it is a three-dimensional construct measured by benevolence, integrity, and competence (Mayer et al. [2]. In addition, trust and inter-organizational cooperation influence each other [21].

\section{B. Assessment of the Confidence Construct}

The results of our empirical study have shown that the operationalization of confidence, within the EIGs and unions surveyed, is based on a measurement scale that takes only two dimensions: integrity and competence. Because of the descriptive statistics technique, we tested the model for measuring confidence if it is adequate with regard to our field of study. Thus, the results obtained are presented as follows:

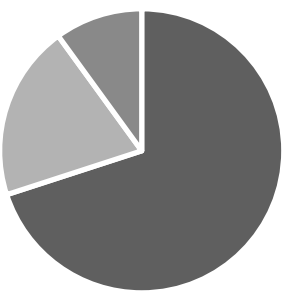

- Benevelance $\|$ integrity $\backsim$ Competence

Fig. 2. the frequencies of the source variables of weak confidence.

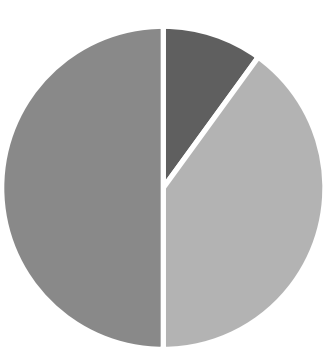

- Bienveillance " Intégrité $॥$ Compétence

Fig. 3. the frequencies of the source variables of strong confidence.

The percentage of respondents who responded to the existence of benevolence in confidence behavior between cooperatives is low (Fig. 2 and 3), which shows that confidence is not synonymous with benevolence for the majority of members. Rather, individual interests are considered more than collective interests. At this level, the majority of respondents affirm the existence of the notion of opportunism and information asymmetry within EIGs and unions. While almost all of the cooperatives confirm that integrity and competence are more likely to explain confidence (Fig. 2 and 3). His findings are confirmed by Fig. 2 and 3, which shows that most cooperatives do not agree that benevolence is a main component of confidence. 
C. Assessment of the Relationship betewwen Confidence and Inter-organizational Cooperation

Inter-organizational cooperation is collective action that calls for confidence either in functional relationships or in informal relationships. However, we will test the relationship between confidence and cooperation, emphasizing the link that may exist between the degree of confidence within EIGs / unions and the appreciation of this cooperation by members (Table XII). In order to check the validity of this relation, we proceed to the Khi2 correlation test.

TABLE XII: THE DEGREE OF SATISFACTION OF COOPERATION AND THE DEGREE OF CONFIDENCE

\begin{tabular}{|c|c|c|c|c|c|c|}
\hline \multirow{7}{*}{ 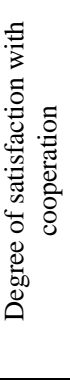 } & \multicolumn{5}{|c|}{ Degree of confidence } & \multirow[b]{2}{*}{ Total } \\
\hline & & 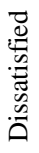 & 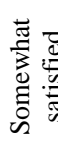 & 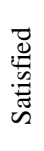 & 궁 & \\
\hline & Dissatisfied & 2 & 2 & 0 & 0 & 4 \\
\hline & Some Satisfied & 5 & 6 & 1 & 2 & 14 \\
\hline & Satisfied & 0 & 4 & 11 & 9 & 24 \\
\hline & Very satisfied & 0 & 0 & 11 & 6 & 17 \\
\hline & Total & 7 & 12 & 23 & 17 & 59 \\
\hline
\end{tabular}

TABLE XIII: THE RELATIONSHIP BETWEEN CONFIDENCE AND COOPERATION

\begin{tabular}{cccc}
\hline \hline Elements & Value & dof & $\begin{array}{c}\text { Asymptotic } \\
\text { significance }\end{array}$ \\
\hline Pearson's chi-square & 36.746 & 9 &, 000 \\
Likelihood ratio & 43.409 & 9 &, 000 \\
$\begin{array}{c}\text { Linear by linear } \\
\text { association }\end{array}$ & 21.844 & 1 &, 000 \\
\# Of valid observations & 59 & & \\
\hline \hline
\end{tabular}

The chi-square indexallows to test the suitability of a data series to a family ofprobability lawsor to test the independence between two random variables. In our case, the chi-square index obtained on this model is 36.746 with nine degrees of freedom, it showsa strong correlation between confidence and inter-organizational cooperation (Table XIII). That is, there is a close relationship between the degree of confidence and the degree of appreciation of cooperation by members. This positive correlation makes it possible to consider that the bonds of confidence are strong between members thanks to the shared objectives and values. In short, the construct of confidence, as it was analyzed by the criteria of Mayer et al. [2], is not confirmed in its entirety within the EIGs and unions surveyed. Confidence within these organizations is based on integrity, through respect for ethical rules and the values of cooperation, and on competence, cooperators confidence members who respect their commitments in the work and who have the ability to meet objectives on time. Nevertheless, the benevolence variable is far from being a main component in the criteria of confidence within our field of study.

\section{DISCUSSION OF THE RESULTS}

On the basis of the results provided by the exploratory and confirmatory factor analysis, as well as the results of the descriptive analysis, we can find that the notion of confidence in the context of Social and Solidarity Economy organizations takes two distinct forms. A strong confidence base of interpersonal relationships and a weak confidence base of organizational relationships. Thus, we were able to organize the ideas raised, based on the reconciliation and proximity of the findings, according to the following two levels of confidence:

Low confidence level: it is a confidence formalized by contracts and writings, this form of confidence is more noticed among EIGs and unions. Several management systems are intended to favor formal interactions between members, becausethe lack of benevolence and indulgence between members weakens the bonds and confidence alone is not enough. In other words, it is necessary to put in place a control system to consolidate confidence. This is the preferred way to improve the level of economic performance of these organizations

High confidence level: it is a confidence based on personal and emotional values; this is the case for the majority of relations between cooperatives. This is mainly based on respect for commitments and competence in concluding their work. In addition, sharing the same culture and the same values promotes this confidence, which helps build a common identity.

In this perspective, inter-organizational cooperation could, depending on the situation, increase or decrease confidence. In other words, the degree of formalization of confidence varies according to the nature of the relationships between partners. Nevertheless, confidence is essential for the stability of the relationship and the maintenance of cooperation. Cooperants, therefore have an interest in developing good relationships based on relational confidence, going beyond its contractual and technical aspect. The collective interest is the basis of cooperation between partners, so this objective can only be achieved if the benevolence of the cooperators is positive towards others. In our case, the criterion of benevolence is weak. However, this benevolence can be acquired over time, while working together; co-workers learn to confidence each other as they interact. In addition, several cooperatives have just joined EIGs or unions, which may explain the results of our study. In conclusion, we have sought to understand the definition of confidence and its relation to cooperation in organizations of the Social and Solidarity Economy. This being the case, our study shows the importance of this confidence within these organizations, because it is thanks to social interactions based on confidence that the entities can build their success and obtain a valuation in the eyes of the other [107], [108].

\section{CONCLUSION}

In conclusion, this study has helped to show that interorganizational cooperation strategies, supported by SSE organizations, are influenced by the components of interorganizational confidence. The GIE and the union are places where members can discuss their practices, their culture, and their profession. This is a way to build confidence through the establishment of common working rules while ensuring a favorable social climate. Confidence is important for these organizations because it maintains the sustainability of their relationships and promotes their development. Confidence, referred to by Mayer et al. [2], is synonymous with kindness, 
integrity, and competence. According to our empirical study, benevolence is far from being an essential component in building confidence; it is a criterion independent of other variables. On the other hand, integrity and competence are considered, by the majority of cooperatives surveyed, as main components in the formation of confidence. In addition, we found a mutual influence between trust and inter-organizational cooperation, notwithstanding that interorganizational cooperation helps to build trust when it is based on the conclusion of good business transactions. In addition, the specificities of SSEOs promote the construction of reciprocal trust and support the need for a collective actor, so that relationships corroborate towards a common interest. Moreover, confidence is a difficult variable to understand and measure because it is part of a dynamic logic rather than a static analysis. A social process develops gradually as relationships develop. Ultimately, the characteristics that can promote trust are reciprocal dependence, good past experiences and closeness in the values and goals of the cooperants. However, it is undoubtedly in the very day-today of the relationship that confidence can best be built through communication, sharing of information and good practices, a sense of responsibility and commitment, etc. Upon which inter-organizational cooperation can rely to develop solid trust and thus contribute to successful and lasting inter-organizational cooperation.

\section{REFERENCES}

[1] Gambetta D., (1988), "Confidence: Making and Breaking Cooperative Relations", Oxford, Blackwell.

[2] Mayer al., (1995), "An integrative model of organizational confidence", Academy of Management Review, 20, 709 -734.

[3] Baudry, B. (2005). The economics of business-to-business relationships. Collection: Landmarks, Pages: 128, Publisher: Discovery.

[4] Forgues B., Fréchet M., Josserand E., (2006),"Inter-organizational relations: Conceptualization, results and avenues of research",French management review2006/5 (no 164), pages 17 to 31 .

[5] Yami S., Le Roy F., (2007), "Collective strategies: a new form of competition", EMS, Caen, 2007.

[6] Axelrod, R. (1984). The Evolution of Cooperation. Vol. 10, No. 2 (Apr. 1985), pp. 368-371. Published by: Academy of Management DOI: 10.2307 / 257983 https://www.jstor.org/stable/257983.

[7] Barnard, C.I. (1938). The functions of the executive. Cambridge, MA: Harvard University Press.

[8] Anderson, E., \& Weitz, B. (1992). The use of pledges to build and sustain commitment in distribution channels. Journal of Marketing Research, vol. 29 (2), pp. 18-34.

[9] Ganesan S., (1994), "Determinates of long-term orientation in buyerseller relationship", Journal of Marketing, vol.58 n.2 April, pp.1-19.

[10] Morgan RM, Hunt SD, (1994), "The commitment-confidence theory of relationship marketing" Journal of Marketing, 58 (3), 20-38.

[11] Doz YL, Hamel G., (1998), "Alliance Advantage", Boston, MA: Harvard Business School Press.

[12] Doney PM, Cannon JP, (1997), "An examination of the nature of confidence in buyer-seller relationships", Journal of Marketing, 61 (2), 35-51.

[13] Dwyer al., (1987), "Developing buyer-seller relationship". Journal of Marketing, 51 (2), 11-27.

[14] Moorman C., Deshpande R., Zaltman G., (1992), "Factors Affecting Confidence in Market", Research Relationships, Journal of Marketing, 57 (January / 93), 81-101.

[15] Andrew, H., \& Van de Ven, (2004). The Appeal and Difficulties of Confidence. Midwest Academy of Management Conference Luncheon Speech Minneapolis, MN, April 30, 2004.

[16] Richez-Battesti N., Malo M., (2012), "ESS and organizational changes". International Social Economy Review, (325), 36-47. https://doi.org/10.7202/1017420ar.
[17] Taratynava N., (2009), "Game theory modeling of forecast exchanges in a network of companies". National School of Mines of Saint-Etienne, 2009. French. NNT: 2009EMSE0034.

[18] Terssac GD, Maggi B., (1996), “Autonomy and design”, Cooperation and Design under the supervision of G. de Terssac and E. Friedberg, Octares Editions, p. 243-266, 1996.

[19] Erschler J., (1996). "Constraint approach for decision support and cooperation: a new logic for using formal models", Cooperation and Design under the direction of G. de Terssac and E. Friedberg, Octares Editions, p. 137-147, 1996.

[20] Boujut, \& al. (2002). Instrumentation of cooperation. Cooperation and knowledge in industrial systems under the supervision of $\mathrm{R}$. Soënen and J. Perrin, Lavoisier, Hermes Science, p. 91-109, 2002.

[21] Campagne JP, Sénéchal O., (2002),"New Cooperation Requirements", Cooperation and Knowledge in Industrial Systems, edited by Soënen R. and Perrin J., Paris, Hermès, 2002.

[22] Le Dain M., Calvi R., Cheriti S., (2011), "Proposition of a tool to evaluate the customer's performance in collaborative product development with suppliers". International Journal on Interactive Design and Manufacturing, Springer Verlag, 2011, 5 (2), pp. 73-83.

[23] Camalot JP, (2000),"Decision support and cooperation in time and resource management", Doctoral thesis in Industrial Systems.

[24] Barthélém, J., \& Fulconis, F., \& Mothe, C., (2001). Interorganizational cooperation: a transversal theoretical approach. In MARTINET, AC.

[25] Kœnig G., (1990), "Strategic management-Vision, maneuvers and tactics", Paris: Nathan.

[26] Kœnig G., (2004), "Strategic management: projects, interactions and context", Paris: Dunod.

[27] Garette B., Dussauge, P., (1995), “Alliance strategies”. Organization editions.

[28] Richardson, G.B. (1972), « The Organization Of Industry », The Economic Journal, n82, p.883-896.

[29] Jensen, M., Meckling, T.W. (1976). « Theory of the firm: managerial behavior, agency cost, and ownership structure » Journal of Financial Economic, 1976, pp. 305-360.

[30] Williamson, O.E. (1981), « Cost escalation and contracting », Center for the Study of Organization. Innovation, University of Pennsylvania, Discussion Paper n ${ }^{\circ}$ 95, janvier 1981.

[31] Williamson, OE (1994), 'The Institutions of the Economy, translated from: The Economic institutions of Capitalism (1985)', InterEditions, Paris, 1994.

[32] Thorelli, B. (1986). "Networks: Between markets and hierarchies", Strategic Management Journal, Volume 7, Issue 1, pages 37-51, January / February 1986.

[33] Jarillo, JC (1988). "On Strategic Networks", Strategic Management Journal 9 (1): 31-41.

[34] Kreps, D. (1990), « Corporate Culture and Economic Theory », in J. E Alt et K. A Shepsle Eds, Perspective on Positive Political Economy, Cambridge University Press.

[35] Anderson JC, Narus, JA (1991). "A model of distributor firm and manufacturer firm working partnerships", Journal of Marketing, 54 42-58.

[36] Everaere, C. (1993). "From costs to transaction investments. For a reversal of Williamson's theory". Revue Française d'Economie, $\mathrm{n}^{\circ}$ VIII, 3, p.149-203.

[37] Hamel, G., \& Prahalad, CK 1994.'Competing fore the future', Havard Business School Press. Boston.

[38] Mohr, J. \& Spekman, R. (1994)."Characteristics of partnership success: Partnership attributes, communication ...". Strategic Management Journal; Feb 1994; 15, 2; ABI / INFORM Global. pg. 135

[39] Hatchuel, A. (1996), "Cooperation and collective conception: variety and crises of prescription relations", in Cooperation and conception, G. de Terssac \& E. Friedberg (eds), Octares Editions, 330 p.

[40] Dussange, al. (2000),"Relational strategies and technological alliance strategy". RFG. Page 7.

[41] Barlatier, 2002. 'Exploration, exploitation and coherence of the firm: the contributions of the network' Conference Paper, June 2002. https://www.researchgate.net/publication/239928998.

[42] Amabile, S. \& Gadille, M. (2006). "Inter-company cooperation, information system and organizational attention”. Revue Française de Gestion, Vol 32/164, 97-118.

[43] Larousse dictionary, 2018.

[44] Rousseau \& al., (1998), "Not so different after all: a cross-discipline view of confidence", Academy of management review.

[45] Bazerman, M.H. (2001). The study of 'real' decision-making. Journal of Behavioral Decision Making, 14: 353-355. Doi: 10.1002 / bdm.382. 
[46] Hackman R., (2003),"Learning more by crossing levels: Evidence from airplanes, hospitals, and orchestras", Journal of Organizational Behavior, 24, 905-922.

[47] Huber, GP., (1990), "A theory of the effects of advanced information technologies on organizational design, intelligence, and decision making”, Fulk \& Steinfield 1990.

[48] Osigweh CAB, (1989), "Casing the case approach in management development", The Journal of Management Development, 8 (2), 41 57.

[49] Bachmann, R., \& Zaheer, A. (2006). Handbook Of trust research. Edward Elgar Publishing. https://doi.org/10.4337/9781847202819.

[50] Fukuyama F., (1995), "Confidence the social virtues and the creation of prosperity", New York The Free Press 1995 p26.

[51] McEvily et al. (2003). "Trust as an Organizing Principle". Organization Science / Vol. 14, No. 1, January - February 2003.

[52] Zucker LG (1986), "Production of Confidence: Institutional Sources of Economic Structure", Research in Organizational Beh.

[53] Antit, I. (2008). "Towards the constitution of optimal confidence: reconciling the economic and the social", 19th congress of the AGRH, Dakar Senegal.

[54] Sitkin, SB, Roth, NL (1993). "Explaning the limited effectiviness of legalistic remedies for trust / distrust", Organization Science, vol. 4 $\mathrm{n}^{\circ} 3$, pp. 367-393.

[55] Éloi, L. (2009). "Ecology and inequalities". OFCE review, 2009/2 n $\circ 109$.

[56] Godé-Sanchez, C. (2002). "Economic analysis of trust», Thesis for the Doctorate of Economics of the University of Aix-Marseille III December 16, 2002.

[57] Sheppard BH, Sherman DM, (1998), "The grammars of trust: A model and general implications", Academy of Management Review, 23, (3): 422-437.

[58] Deutsch M., (1958), “Confidence and suspicion,” Journal of Conflict Resolution, 2,265-279.

[59] Johnson-George C., Swap W., (1982), "Measurement of specific interpersonal confidence: Construction and validation of a scale to assess confidence in a specific other", Journal of Personality and Social Psychology, 43, 1306-1317.

[60] Gillespie NA, Mann L., (2004), "Transformational leadership and shared values: The building blocks of confidence", Journal of Managerial Psychology. 19, 6.588-607.

[61] Gillespie NA, (2003), "Measuring confidence in working relationships: the behavioral confidence inventory", the 2003 Annual Meeting of the Academy of Management, Seattle, Washington.

[62] Serva MA, Fuller MA, Mayer RC, (2005), "The reciprocal nature of confidence: A longitudinal study of interacting teams", Journal of Organizational Behavior, 26: 625-648.

[63] Hall \& al., (2004), "Leader reputation and accountability in organizations: implications for dysfunctional leader behavior", Leadership Quaterly, 15, 515-536.

[64] Lewicki RJ, Bunker BB, (1995), "Confidence in relationships: a model of confidence development and decline", in Bunker, BB \& Rubin, JZ Conflict, Cooperation and Justice, San Francisco, JosseyBass.

[65] Williams M., (2001), "In whom we confidence: group membership as an affective context for confidence development", Academy of Management Review, 26 (3), 377-396.

[66] McKnight al., (1998), "Initial confidence formation in new organizational relationships", Academy of Management Review, 23 (3), 473-490.

[67] Boughanbouz, C. (2015). "The determining factors of interorganizational confidence in innovation networks. The case of the Alsace Energivie competitiveness cluster". Doctoral thesis in Management Sciences.

[68] Inkpen \& Currall, (2004). "The Coevolution of Trust, Control, and Learning in Joint Ventures". Organization Science Vol. 15, No. 5, September - October 2004, pp. 586-599.

[69] Ouchi, WG (1980). "Markets, Bureaucracies, and Clans". Administrative Science Quarterly, 25 (1): 129-141.

[70] Assens, C. (2013). "Network management - Weaving social links for economic well-being" (1st edition). De Boeck.

[71] Fulconis, F. \& Paché, G. (2008). "Strategic management of interorganizational networks put to the test of opportunistic behavior: development of an analytical framework". Direction and Management | "La Revue des Sciences de Gestion" 2008/2 n ${ }^{\circ} 230$ pages 35 to 43 ISSN 1160-7742.

[72] Margit Enke, 2006. "Markenwert und Markenidentität komplexer Handelsleistungen: Konzeption und Analyze am Beispiel der Betriebsformenmarke Warenhaus". German Edition.

[73] Pavlou PA, (2002), "Consumer Acceptance of Electronic Commerce - Integrating Trust and Risk with the Technology Acceptance
Model", International Journal of Electronic Commerce, Vol. 7, No. 2, 2002/03

[74] Bergadaà \& al. (1999). Confidence in the tripartite seller-clientbusiness relationship. Proceedings of the 15th International Congress of the French Marketing Association, Strasbourg, 283-299.

[75] Smith, JB, Barclay, DW (1997). "The Effects of Organizational Differences and Trust on the Effectiveness of Selling Partner Relationships", Journal of Marketing, vol.61, pp.3-21.

[76] Jarvenpaa SL, Leidner DE, (1998), "Communication and trust in global virtual teams", Journal of Computer Mediated Communication, 3 (4), 1-36.

[77] Kouzes JM, Posner BJ, (2002), "Leadership challenge”, (3rd ed.) San Francisco: Jossey-Bass.

[78] Schoorman \& al., (2007), “An integrative model of” organizational confidence: past, present, and future", Academy of Management Review, 32 (2): 344-354.

[79] Mc Allister DJ, (1995), "Affect and Cognition Based Confidence as Foundation for Interpersonnal

[80] Cooperation in Organizations", Academy of Management Journal, Vol 38, 24 - 59.

[81] Jeffries FL, Reed R. (2000), "Confidence and Adaptation In Relational Contracting", Academy of Management Review, vol. 25 $\mathrm{n}^{\circ} 4$, p. 873-882.

[82] Mishra AK, (1996), "Organizational responses to crisis: The centrality of confidence", in RM Kramer \& TR Tyler (Eds.) Confidence in Organizations: Frontiers of Theory and Research: 261 287. Thousand Oaks, CA: Sage.

[83] Giffin K., (1967), "The contribution of studies of source credibility to a theory of interpersonal confidence in the communication department", Psychological Bulletin, 68: 104-120.

[84] Andaleeb, SS. (1992). "The Confidence Concept: Research Issues for Channel of Distribution", Research in Marketing, Vol. 11, Jai Press Inc., pp. 1-34.

[85] Blomqvist, K., (2002). "Partnering in the Dynamic Environment: The Role of Confidence in Asymmetric Technology Partnership Formation". Lappeenrantaensis, Acta Universitatis.

[86] Gurviez P \& Korchia M., 2002, 'Proposal of an multidimensional measurement scale of brand confidence' research and application in marketing, 17,3, 41-59.

[87] Atuahene-Gima, K., \& Haiyang, L. (2002). "When does confidence matter? Antecedents and contingent effects of supervisee confidence on performance in selling new products in China and the United States". Journal of Marketing, Vol. 66, No. 3.81.

[88] Kouzes JM, Posner BJ, (2002), "Leadership challenge”, (3rd ed.). San Francisco: Jossey-Bass.

[89] Schoorman \& al., (2007), "An integrative model of" organizational trust: past, present, and future", Academy of Management Review 32 (2): 344-354.

[90] Biswas, S., \& Varma, A. (2007). "Psychological climate and individual performance in India: Test of a mediated model". Employee Relations, 29, 664-676.

[91] Peillon S., (2001), "The management of inter-company cooperation: the case of groups of SMEs", Thesis for the doctorate in economics, École nationale supérieure des mines de Saint-Étienne, Jean-Monnet University, October 3

[92] Nooteboom, (1997), "Effects of Confidence and Governance on Relational Risk" Academy Management Journal, Vol. 40, No. 2 1997, pp. 308-338.

[93] Brousseau, G. (1997). Theory of Didactical Situations in Mathematics. Kluwer academic publishers.

[94] Mahoui K., Ferfera, MY, (2013), "Analysis of the modes of interorganizational coordination in the case of relations between companies and companies-public institutions", CREAD notebooks n 104-2013.

[95] Tremblay D., (2002),"Solidarity economy in the world of international and transnational relations: balancing confidence and misconfidence". New Social Practices, 15 (1), 25-39. https://doi.org/10.7202/008259ar.

[96] Bauman, (1999), "The human cost of globalization", Hatchet, 1999.

[97] Lewicki RJ, Bunker BB, (1996), "Developing and maintaining confidence in work relationships", in Kramer, RM and Tyler, TR (Eds), Confidence in Organizations: Frontiers of Theory and Research, Sage, Thousand Oaks, CA, pp. 114-39.

[98] Williams M., (2001), "In whom we trust: group membership as an affective context for trust development », Academy of Management Review, 26 (3), 377-396.

[99] Zaheer, A., \& al. (1998), 'Does trust matter? Exploring the effects of inter-organizational and interpersonal trust on performance', Organization Science, 9, 141-59. 
[100]Khalifa AH, Kammoun M., (2013), "Interpersonal confidence and organizational confidence in the client-service provider relationship: the case of the client-bank relationship", Revue des Sciences de Gestion, 2013 / 3-4 (N²61-262), pages 167 to 174 .

[101]Breton, A., \& Wintrobe, R. (1982). "The logic of bureaucratic conduct. An economic analysis of competition, exchange and efficiency in private and public organizations", Cambridge, Cambridge University Press, 1982.

[102]Berahmani, \& al. (2016). "The Phoenicultural Economic Interest Groups of Tafilal and: contrasting collective capacities". Alternatives Rurales (4), October 2016, pp.1-14.

[103]IFA. The Interprofessional Federation of the Argan Sector.

[104]Everaere, C. (1993). "From costs to transaction investments. For a reversal of Williamson's theory". Revue Française d'Economie, n VIII, 3, p.149-203

[105]Roussel, P. 1996. "Compensation, motivation and job satisfaction". Paris: Economica Editions.

[106]Roehrich, G., (1994), «Hedonistic and social innovations: proposal for a measurement scale", Recherche et Application en Marke-ting, Vol. 10, $\mathrm{n}^{\circ} 2$, pp 19-42.

[107]Igalens J., Roussel P. (1988), «Research Methods in Human Resources Management”, Economica.

[108]Paugam, S. (2008), 'The social connection', Paris, PUF.

[109]Honneth, Axel (2008). The society of contempt: towards a new critical theory, Paris, La Découverte, coll. 'Pocket books'. 